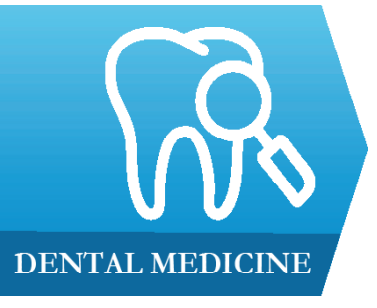

1) Department of Prosthetics and Dental Materials, Iuliu Hatieganu University of Medicine and Pharmacy, Cluj-Napoca, Romania

2) Department of Dental Medicine, Faculty of Medicine and Pharmacy, Dunarea de Jos University, Galati, Romania

DOI: $10.15386 / \mathrm{mpr}-1413$

Manuscript received: 04.07.2019

Received in revised form: 11.10.2019

Accepted: 28.10.2019

Address for correspondence:

danico_81@yahoo.com

This work is licensed under a Creative Commons Attribution-NonCommercialNoDerivatives 4.0 International License

\title{
Moorrees-like mesh diagram for Romanian patients - a pilot study
}

\author{
Daniela Cornea ${ }^{1}$, Mioara Decusara ${ }^{2}$, Gicuta Dolea ${ }^{2}$, \\ Alexandru Mircea Nicolau ${ }^{2}$
}

\begin{abstract}
Background and aims. In 1976, Coenraad F.A. Moorrees completed a series of facial mesh diagrams to ease the orthodontic diagnosis and treatment of NorthAmerican patients. Subsequently, the system was adapted by different authors to other races and populations. The objective of this study is to provide a system of Moorrees-like mesh diagrams for the Romanian population, Caucasian race, which would help orthodontists, surgeons and prosthetists.
\end{abstract}

Methods. 40 patients were introduced in the study, 20 males and 20 females, with ages between 12-33 years, permanent dentition and slight dental-maxillary abnormalities, class I and II Angle. For each patient, a lateral cephalometric radiograph was taken, with CRANEX $3 \mathrm{D}$, head straight, maximum intercuspation. On tracing paper were drawn 35 anthropometric points and 3 planes, Frankfurt plane, as the horizontal landmark, a perpendicular line through nasion as the vertical landmark and the occlusal plane. From each point we measured the distance in millimeters to the horizontal landmark and to the vertical landmark, respectively. The obtained values were introduced into 40 tables, using Microsoft Office Excel 2007 and 3 arithmetic means were calculated, for males, for females and a general one, for children under 12 years old. The arithmetic means were transferred on millimetric paper and tracing paper, joining the obtained points and completing the templates.

Results. Three different Moorrees-like mesh diagrams were obtained, one for male, one for female and a mixt one for children under 12 years, Romanian patients, Caucasian race, respectively.

Conclusions. Mesh diagram comes in the support of a better perspective of the anatomical elements of the face and the facial growth, being a useful tool in predicting treatment. Computer based programs with Moorrees-like diagrams adapted to Romanian patients may be the object of further studies.

Keywords: Moorrees, mesh diagram, Romanian patients

\section{Background and aims}

Facial beauty is not static or constant, in fact change is the constant. This is documented by the work of many artists, starting in antiquity, continuing with the Renaissance period which culminates with the famous templates of Leonardo da Vinci. In the modern era, Albrecht Durer and his contemporaries have deepened the facial aesthetic studies [1,2]. Aesthetic requests of the patients are increasing, so an orthodontic examination is necessary not only for aesthetic reasons, but also to complete an odontological and prosthetic examination.
The value of radiography in orthodontics, as a diagnostic method, was mentioned for the first time in 1905, by Price, 5 years after the discovery of X-rays. Lateral cephalometrics was conducted in 1922 by Carrea, and radiological imaging technique for obtaining profile teleradiography was introduced in 1931 by Broadbent and Bolton. They also inaugurated the use of cephalostat in orthodontics [3]. Teleradiography provides on a single image the structure of all the elements of the dentomaxillary system: teeth, alveolar ridges, jawbones, maxillary sinuses, nasal bones, bones of the skull, 
cervical vertebrae and hyoid bone. All these elements can be analyzed in order to establish an individualized diagnosis and a treatment plan accordingly $[4,5]$.

Interpretation techniques of lateral cephalometrics are particularly numerous; any practitioner usually selects one or two techniques, although they do not have the same sensitivity for any type of abnormality. The multitude of interpretation methods can be reduced to three: metric, angular and superimposing techniques [3]. The superimposing method, the simplest for a practitioner, implies the existence of specific patterns, for the respective population, by age and sex.

Coenraad F.A. Moorrees developed on the bases of superimposing method, a system of templates, to study the most important facial aspects for orthodontic treatment. This is a method that allows appreciation of the proportion and relationships between different facial components and highlights existent changes in sagittal, vertical and transverse directions as well as facial dysmorphias and soft tissue modifications. In the $8^{\text {th }}$ decade of the last century, Moorrees imagined a mesh diagram (template), corresponding to the population of North America, that allowed the assessment and the primary comparative diagnosis of patients, in order to establish a more predictable and effective treatment, the final version of the diagram being published in 1976 [6,7]. Understanding craniofacial growth and development is important for the accurate diagnosis, treatment planning and post-treatment evaluation of orthodontic cases [8]. Mesh analysis provides novel graphical as well as quantitative method of assessing craniofacial growth [9].

Because of the success in achieving the goal of Moorrees, different specialists, in different countries and regions of the world, have improved the properties of this diagram, corresponding to their population, while observing that each population has its anthropological characteristics. This means that the existence of one single diagram for the entire population would be a major source of therapeutic errors.

For this reasons, the aim of our study was to create a Moorrees-like mesh diagrams for Romanian population, which could be used in the evaluation and proper treatment of dental and maxillary abnormalities in the cephalic region. Also, mesh diagrams are a useful tool, not only to orthodontists, but also to prosthetists and orthognathic surgeons.

\section{Methods}

In the current study were included a total of 40 subjects $(\mathrm{n}=40)$, Romanian patients, 20 men and 20 women, ages between 12 and 33, with permanent dentition and minor abnormalities, class I and II Angle. Lateral cephalometrics were performed with CRANEX 3D radiographic device (Figure 1), heads oriented in natural head position. There were 40 radiological films obtained, transparent, bending resistant, with a standard size at a 1:1 scale.

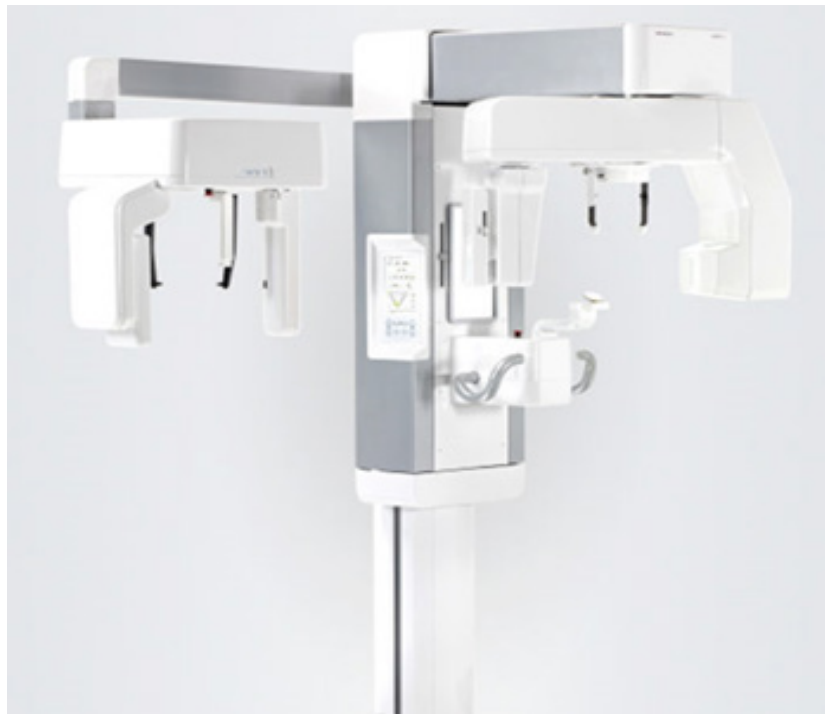

Figure 1. CRANEX 3D radiographic device

Table I. Anthropometric points marked on tracing paper.

N Nasion

Or Orbitale

$\mathbf{K r} \quad$ key ridge, the lowest point on the zygomatic bone

Ptm uppermost and posterior point of the pterygo-maxillary

fossa

S Sellae

Ba Basion

Cp condyl posterior, radiologic and bony point posterior and lateral to mandibular condyle

Ca condyl anterior, radiologic and bony point anterior and lateral to mandibular condyle

Mpb mandibular posterior branch, a posterior point on the upward branch of the mandible

Mab mandibular anterior branch, an anterior point on the upward branch of the mandible

Go Gonion

Gn Gnathion

Po Pogonion

B B Down point

Ls lower symphysis, located lower on the chin

Us upper symphysis, upper on the chin

Ii incisale inferius

Is incisale superius

Aop anterior occlusal plane

Pop posterior occlusal plane

A A Down point

Ans anterior nasal spine

Pns posterior nasal spine

Tg tegumentary glabella

Tn tegumentary nasion

Sn Subnasale

Ls labiale superius

Li labiale inferius

St Stomion

Lmg labiomentonier groove

Tp tegumentary pogonion

Pn Pronasale

Mia maxillary incisor apex

Mia mandibular incisor apex 
Lateral cephalometrics were positioned on a viewing box, with the patient's face towards the right, over which tracing paper was provisionally fastened. Patient's name, surname, age and doctor's name were marked on tracing paper. Also, 35 anthropometric points used by Moorrees were marked on tracing paper (Table I).

Also, 3 planes used by Moorrees were marked on tracing paper (Table II).

Table II. Planes marked on tracing paper.

\begin{tabular}{|c|c|}
\hline Fhp & $\begin{array}{l}\text { Frankfort horizontal plane- a line } \\
\text { that joins Orbitale inferius with } \\
\text { Porion }\end{array}$ \\
\hline VptN & $\begin{array}{l}\text { Vertical plane through Nasion- } \\
\text { a perpendicular on Frankfurt } \\
\text { horizontal line }\end{array}$ \\
\hline Op & $\begin{array}{l}\text { Occlusal plane- an imaginary } \\
\text { line passing between the upper } \\
\text { molars cusps and the incisal } \\
\text { edges of the inferior frontal teeth. }\end{array}$ \\
\hline
\end{tabular}

The distance between each anthropometric point to the horizontal and vertical plane was measured, with an electronic calliper for each patient (Figure 2). The dates were processed with Microsoft Office Excel 2007 and 40 tables were obtained.

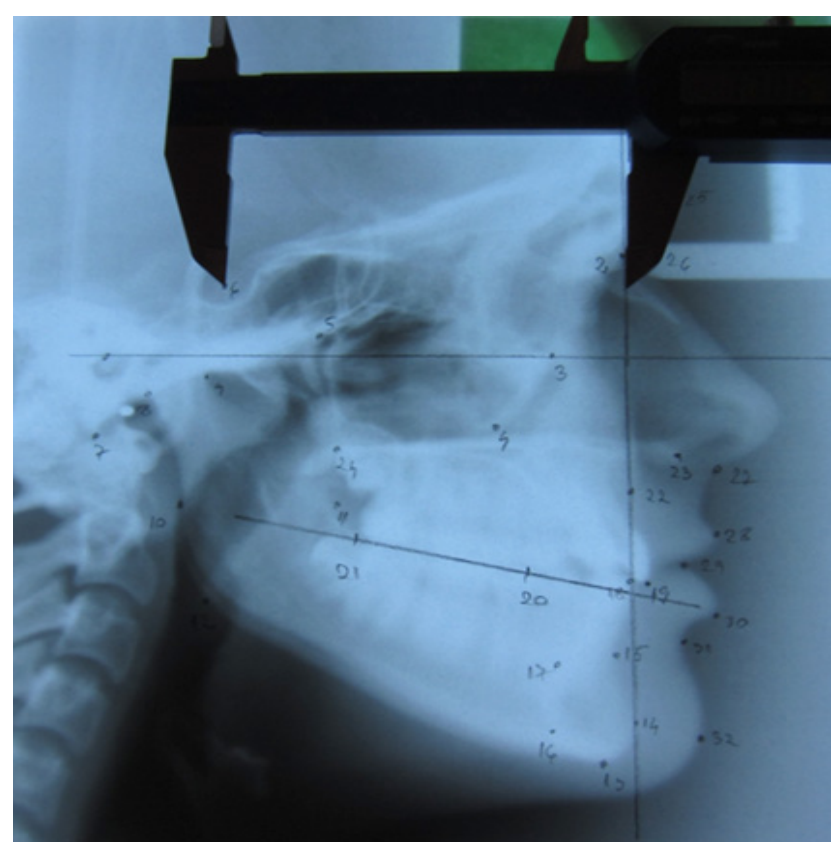

Figure 2. Measuring the distance between $\mathrm{S}$ and $\mathrm{VptN}$

For horizontal and vertical measurements arithmetic means were calculated. Three arithmetic means resulted: one for men, one for women and a general one, that have been used to build a diagram for the treatment of children, up to 12 years (Tables III, IV, V).
The next steps in the construction of the template required transferring the distance resulted from the arithmetic means on millimetric paper, according to the tables (Figures 3,4,5). The first line transferred is the horizontal line from Frankfort. In front of it, the $\mathrm{N}$-point is positioned vertically, according to the table. The vertical line through $\mathrm{N}$ is drawn perpendicular to the horizontal from Frankfort. Two horizontal lines are drawn, perpendicular to this vertical plane, through $\mathrm{N}$ and ANS. One last vertical line, parallel with the vertical line through $\mathrm{N}$, goes through $\mathrm{S}$. The basic diagram thus obtained is divided into four equal parts, by two coordinates. Two vertical units are added before and after the divided diagram, two horizontal units are added in the upper part and six in the lower part. Finally, twenty-four identical rectangles will form a mesh diagram. The rest of the anthropometric points are added by measuring the distance to horizontal and vertical lines, according to the tables.

Using the superimposing method, the obtained template was transferred on tracing paper. Finally, by joining the points, three Moorrees-like mesh diagrams resulted for Romanian patients, taken under study: men, women and children under 12 years old (Figures 6,7,8).

\section{Results}

The dates were processed with Microsoft Office Excel 2007.

The arithmetic mean of each point in relation to horizontal and vertical planes are presented in tables III, IV and V.

The templates on millimetric paper are listed on figures 3,4 and 5 .

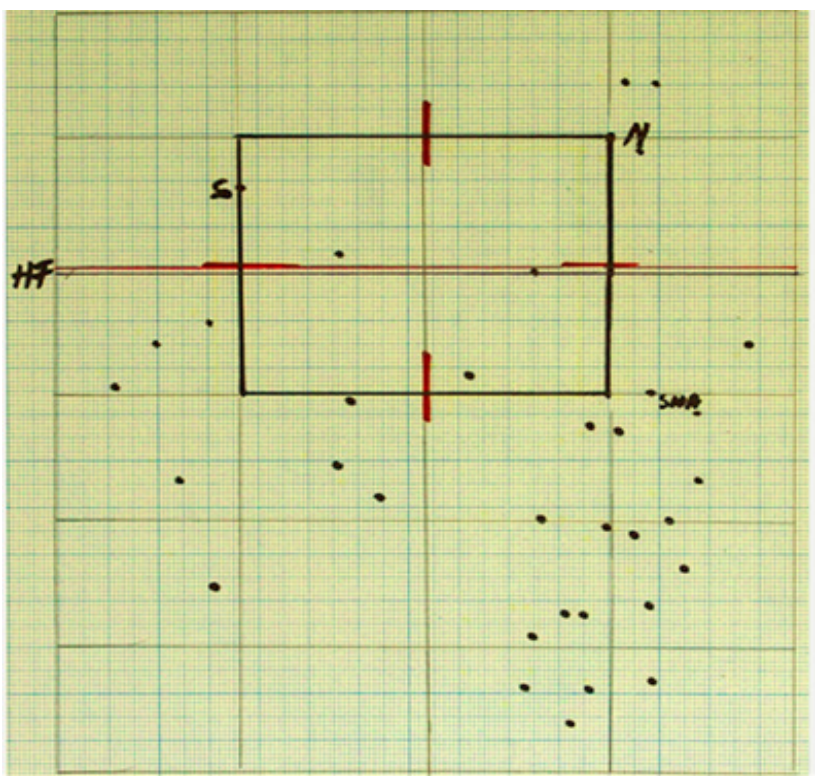

Figure 3. Mesh diagram for men on millimetric paper. 


\section{Dental Medicine}

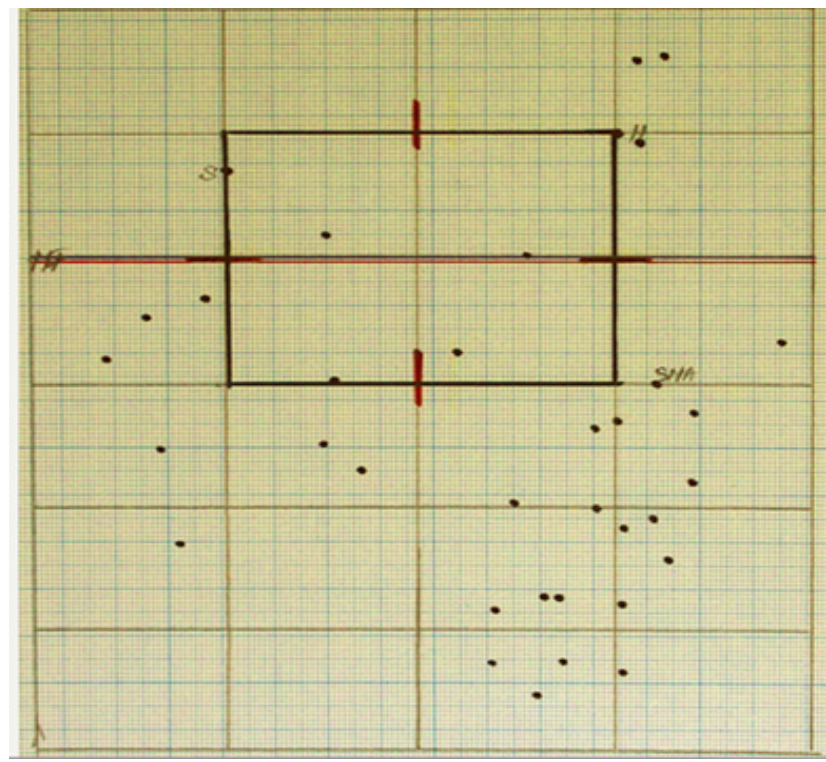

Figure 4. Mesh diagram for women on millimetric paper.

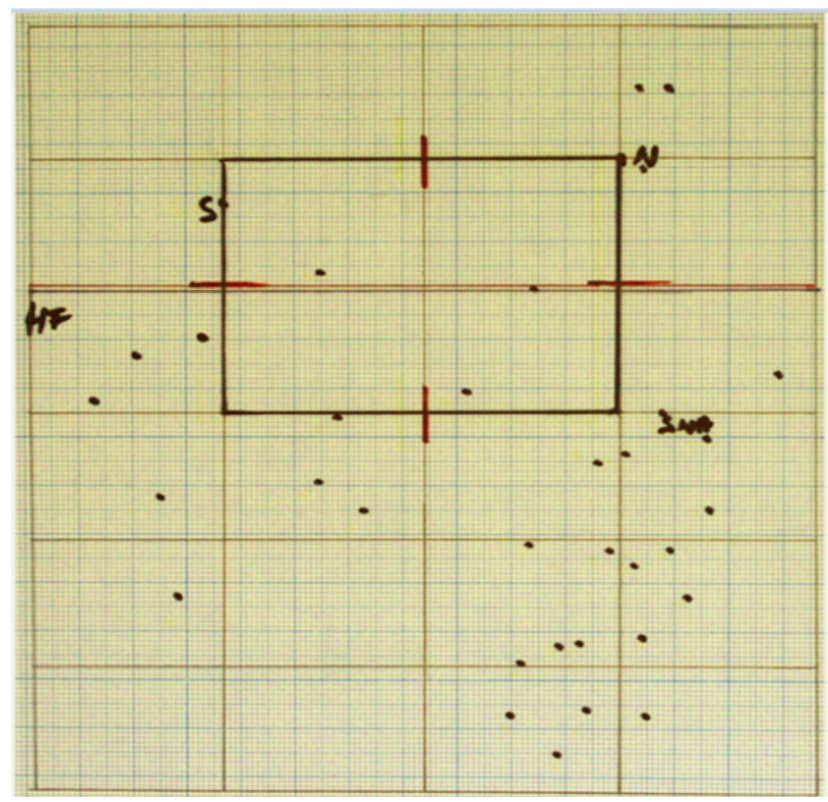

Figure 5. Mesh diagram for children under 12 years old, on millimetric paper.
Table III. Arithmetic means for men.

\begin{tabular}{|c|c|c|}
\hline $\begin{array}{l}\text { Anthropometric } \\
\text { points }\end{array}$ & $\begin{array}{c}\text { Horizontal } \\
\text { measurements }\end{array}$ & $\begin{array}{c}\text { Vertical } \\
\text { measurements }\end{array}$ \\
\hline Glabela & -2.76 & -41.21 \\
\hline Nasion & 0 & 28.54 \\
\hline Orbitale & 14.84 & 0 \\
\hline Key ridge & 28.38 & 22.1 \\
\hline PTM & 54.35 & 3.53 \\
\hline Sellae & 73.84 & 18.88 \\
\hline Basion & 98.28 & 23.35 \\
\hline Condyl posterior & 90.56 & 14.41 \\
\hline Condyl anterior & 78.37 & 10.07 \\
\hline $\begin{array}{l}\text { Mandibular posterior } \\
\text { branch }\end{array}$ & 84.82 & 43.12 \\
\hline $\begin{array}{l}\text { Mandibular anterior } \\
\text { branch }\end{array}$ & 53.93 & 40.3 \\
\hline Gonion & 79.23 & 66.1 \\
\hline Gnathion & 8.38 & 95.2 \\
\hline Pogonion & 3.77 & 88.1 \\
\hline B Down point & 5.33 & 72.35 \\
\hline Lower symphysis & 16.92 & 88.53 \\
\hline Upper symphysis & 16.49 & 76.85 \\
\hline Incisale inferius & 0.13 & 52.59 \\
\hline Incisale superius & -3.76 & 55.23 \\
\hline $\begin{array}{l}\text { Anterior occlusal } \\
\text { plane }\end{array}$ & 14.12 & 52.26 \\
\hline $\begin{array}{l}\text { Posterior occlusal } \\
\text { plane }\end{array}$ & 46.16 & 46.96 \\
\hline A Down point & -1.16 & 32.75 \\
\hline ANS & -7.02 & 24.53 \\
\hline PNS & 51.89 & 25.87 \\
\hline Tegumentary glabella & -8.68 & -40.45 \\
\hline Tegumentary nasion & -4.86 & -25.59 \\
\hline Subnasale & -16.03 & 29.45 \\
\hline Labiale superius & -17.4 & 43.92 \\
\hline Stomion & -10.71 & 51.98 \\
\hline Labiale inferius & -14.08 & 62.35 \\
\hline $\begin{array}{l}\text { Labiomentonier } \\
\text { groove }\end{array}$ & -6.43 & 70.11 \\
\hline $\begin{array}{l}\text { Tegumentary } \\
\text { pogonion }\end{array}$ & -8.06 & 86.58 \\
\hline Pronasale & -27.58 & 15.59 \\
\hline $\begin{array}{l}\text { Maxillary incisor } \\
\text { apex }\end{array}$ & 3.91 & 33.72 \\
\hline $\begin{array}{l}\text { Mandibular incisor } \\
\text { apex }\end{array}$ & 9.42 & 73.23 \\
\hline
\end{tabular}


Table IV. Arithmetic means for women.

\begin{tabular}{|c|c|c|}
\hline $\begin{array}{l}\text { Anthropometric } \\
\text { points }\end{array}$ & $\begin{array}{c}\text { Horizontal } \\
\text { measurements }\end{array}$ & $\begin{array}{c}\text { Vertical } \\
\text { measurements }\end{array}$ \\
\hline Glabela & -3.58 & -41.15 \\
\hline Nasion & 0 & 25.49 \\
\hline Orbitale & 16.38 & 0 \\
\hline Key ridge & 29.39 & 20.32 \\
\hline PTM & 54.62 & 3.91 \\
\hline Sellae & 72.22 & 17.99 \\
\hline Basion & 96.02 & 22.3 \\
\hline Condyl posterior & 88.87 & 12.82 \\
\hline Condyl anterior & 76.54 & 9.21 \\
\hline $\begin{array}{l}\text { Mandibular posterior } \\
\text { branch }\end{array}$ & 85 & 41.25 \\
\hline $\begin{array}{l}\text { Mandibular anterior } \\
\text { branch }\end{array}$ & 54.61 & 39.33 \\
\hline Gonion & 81.49 & 60.35 \\
\hline Gnathion & 14.68 & 93.28 \\
\hline Pogonion & 9.83 & 85.78 \\
\hline B Down point & 10.6 & 72.04 \\
\hline Lower symphysis & 23.72 & 85.96 \\
\hline Upper symphysis & 20.36 & 74.95 \\
\hline Incisale inferius & 3.19 & 53.2 \\
\hline Incisale superius & -0.79 & 57.26 \\
\hline $\begin{array}{l}\text { Anterior occlusal } \\
\text { plane }\end{array}$ & 19.6 & 51.83 \\
\hline $\begin{array}{l}\text { Posterior occlusal } \\
\text { plane }\end{array}$ & 48.77 & 45.02 \\
\hline A Down point & 0.24 & 34.78 \\
\hline ANS & -7.26 & 27.08 \\
\hline PNS & 52.92 & 26.29 \\
\hline $\begin{array}{l}\text { Tegumentary } \\
\text { glabella }\end{array}$ & -9.14 & -41.66 \\
\hline Tegumentary nasion & -3.72 & -23.56 \\
\hline Subnasale & -14.74 & 32.16 \\
\hline Labiale superius & -14.35 & 47.08 \\
\hline Stomion & -7.15 & 54.55 \\
\hline Labiale inferius & -10.2 & 64.62 \\
\hline $\begin{array}{l}\text { Labiomentonier } \\
\text { groove }\end{array}$ & -0.98 & 72.79 \\
\hline $\begin{array}{l}\text { Tegumentary } \\
\text { pogonion }\end{array}$ & -1.15 & 87.91 \\
\hline Pronasale & -30.72 & 18.33 \\
\hline $\begin{array}{l}\text { Maxillary incisor } \\
\text { apex }\end{array}$ & 4.42 & 36.17 \\
\hline $\begin{array}{l}\text { Mandibular incisor } \\
\text { apex }\end{array}$ & 13.92 & 71.54 \\
\hline
\end{tabular}

Table V. General arithmetic means for children under 12 years old.

\begin{tabular}{|c|c|c|}
\hline $\begin{array}{l}\text { Anthropometric } \\
\text { points }\end{array}$ & $\begin{array}{c}\text { Horizontal } \\
\text { measurements }\end{array}$ & $\begin{array}{c}\text { Vertical } \\
\text { measurements }\end{array}$ \\
\hline Glabela & -3.17 & -41.18 \\
\hline Nasion & 0 & 27.01 \\
\hline Orbitale & 15.61 & 0 \\
\hline Key ridge & 28.88 & 21.21 \\
\hline PTM & 54.48 & 3.72 \\
\hline Sellae & 73.03 & 18.43 \\
\hline Basion & 97.15 & 22.82 \\
\hline Condyl posterior & 89.71 & 13.61 \\
\hline Condyl anterior & 77.45 & 9.64 \\
\hline $\begin{array}{l}\text { Mandibular } \\
\text { posterior branch }\end{array}$ & 84.91 & 42.18 \\
\hline $\begin{array}{l}\text { Mandibular anterior } \\
\text { branch }\end{array}$ & 54.27 & 39.81 \\
\hline Gonion & 80.36 & 63.22 \\
\hline Gnathion & 11.53 & 94.24 \\
\hline Pogonion & 6.8 & 86.94 \\
\hline B Down point & 7.96 & 72.19 \\
\hline Lower symphysis & 20.32 & 87.24 \\
\hline Upper symphysis & 18.42 & 75.9 \\
\hline Incisale inferius & 1.66 & 52.89 \\
\hline Incisale superius & -2.27 & 56.24 \\
\hline $\begin{array}{l}\text { Anterior occlusal } \\
\text { plane }\end{array}$ & 16.86 & 52.04 \\
\hline $\begin{array}{l}\text { Posterior occlusal } \\
\text { plane }\end{array}$ & 47.46 & 45.99 \\
\hline A Down point & -0.46 & 33.76 \\
\hline ANS & -7.14 & 25.8 \\
\hline PNS & 52.4 & 26.08 \\
\hline $\begin{array}{l}\text { Tegumentary } \\
\text { glabella }\end{array}$ & -8.91 & -41.05 \\
\hline Tegumentary nasion & -4.29 & -24.57 \\
\hline Subnasale & -15.38 & 30.8 \\
\hline Labiale superius & -15.87 & 45.5 \\
\hline Stomion & -8.93 & 53.26 \\
\hline Labiale inferius & -12.14 & 63.48 \\
\hline $\begin{array}{l}\text { Labiomentonier } \\
\text { groove }\end{array}$ & -3.7 & 71.45 \\
\hline $\begin{array}{l}\text { Tegumentary } \\
\text { pogonion }\end{array}$ & -4.6 & 87.24 \\
\hline Pronasale & -29.15 & 16.96 \\
\hline $\begin{array}{l}\text { Maxillary incisor } \\
\text { apex }\end{array}$ & 4.16 & 34.94 \\
\hline $\begin{array}{l}\text { Mandibular incisor } \\
\text { apex }\end{array}$ & 11.67 & 72.38 \\
\hline
\end{tabular}


The final diagrams are presented in figures 6,7 and 8 .

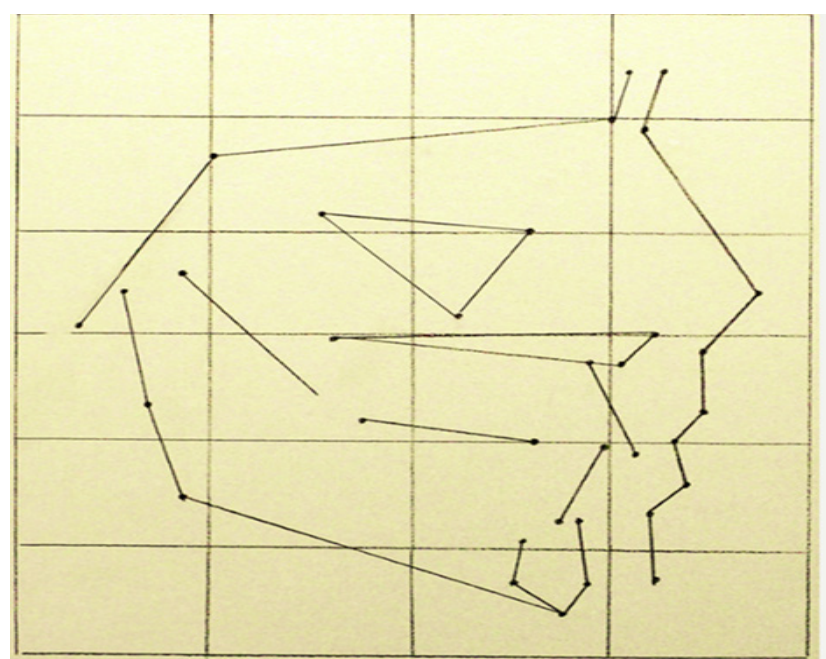

Figure 6. Moorrees-like mesh diagram for men.

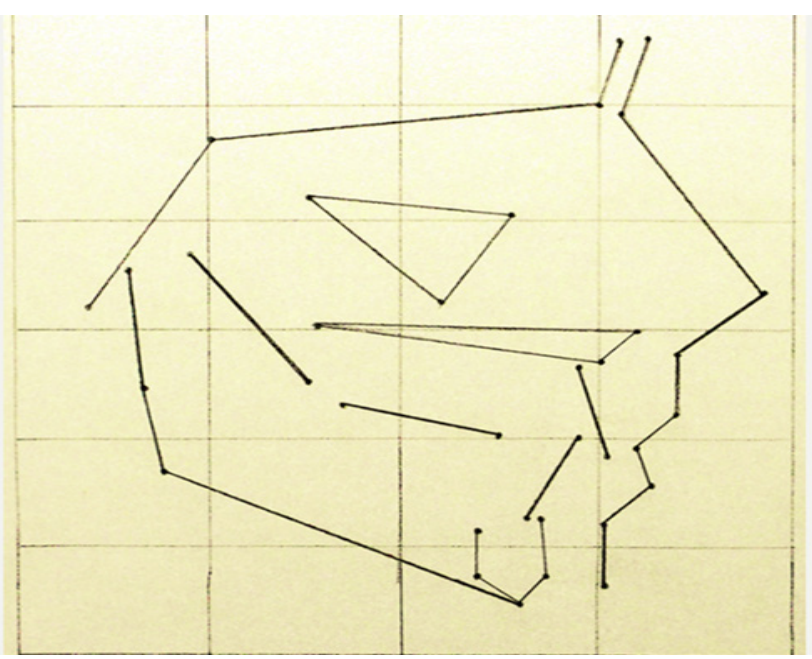

Figure 7. Moorrees-like mesh diagram for women.

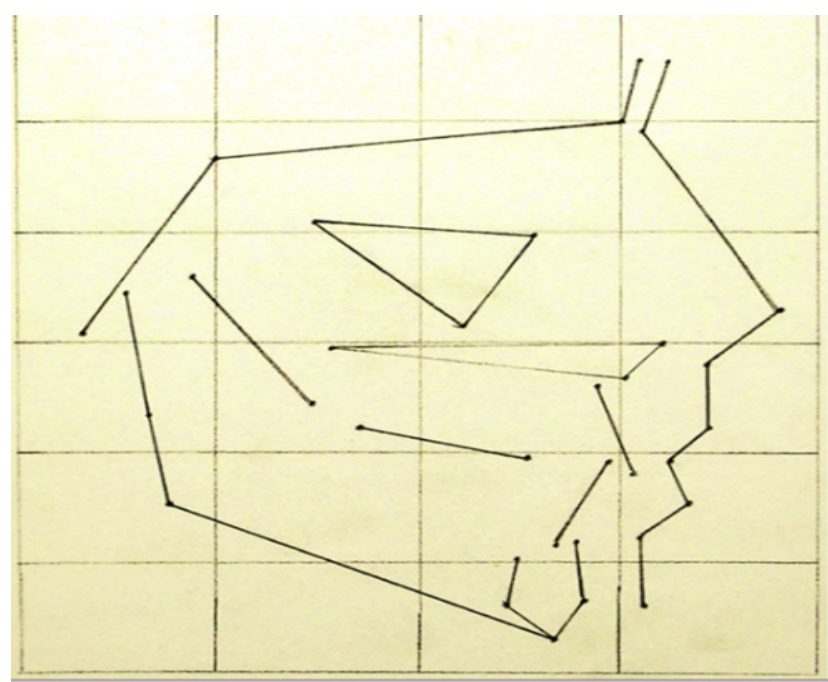

Figure 8. Moorrees- like mesh diagram for children under 12.

\section{Discussion}

The diagrams obtained were used in orthodontic patients, superimposing it on individual cephalometrics at $\mathrm{N}$ - point level, by rotating the diagram progressively until the horizontal and vertical reference line overlap. At this time a deviation from the standard norms, as they resulted from the diagrams, was established, facilitating the orthodontic and surgical treatment plan $[10,11]$. Clinical implications such as rotation of the mandible, position of the occlusal plane, position of the incisors and of the chin, have been noticed (Figures 9, 10).

Processing of lateral cephalometrics has greatly diversified, yet there is no unitary method. While approving anthropometric points, freedom of interpretation is allowed for establishing the diagnosis of abnormality. Anthropometric points used by Moorrees are the ones described by Martin and Saller in classical anthropometry [12]. The construction of the diagram was carried out in several stages: a. the horizontal line from Frankfort; b. the vertical line through $\mathrm{N}$-point, that serves as origin for the coordinate system of the diagram, on which ANS is projected; $c$. the length of the anterior skull base (SN); d. two horizontal lines, perpendicular to the vertical plane, through $\mathrm{N}$ and ANS; e. one last vertical line through S-point, parallel to the vertical line through $\mathrm{N}$-point. The diagram built is divided into 4 equal units by a horizontal line and a vertical one, 2 vertical units are added before and after the divided diagram, 2 horizontal units are added in the upper part and 3 times 2 horizontal units in the lower part. Finally, 24 identical rectangles will form a mesh diagram $[13,14]$. All these steps have been observed in the construction of the mesh diagram for Romanian patients.

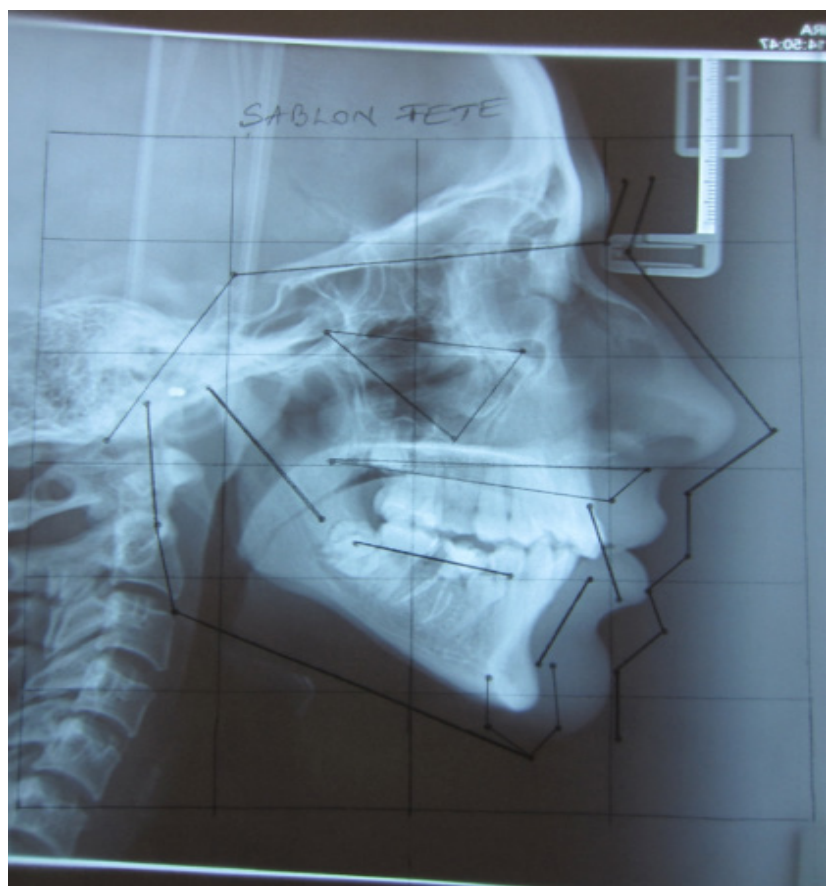

Figure 9. D.Z., female, 22 years, Angle Class I, posterior rotated mandible, high occlusion plan, retruded mandibular incisors. 


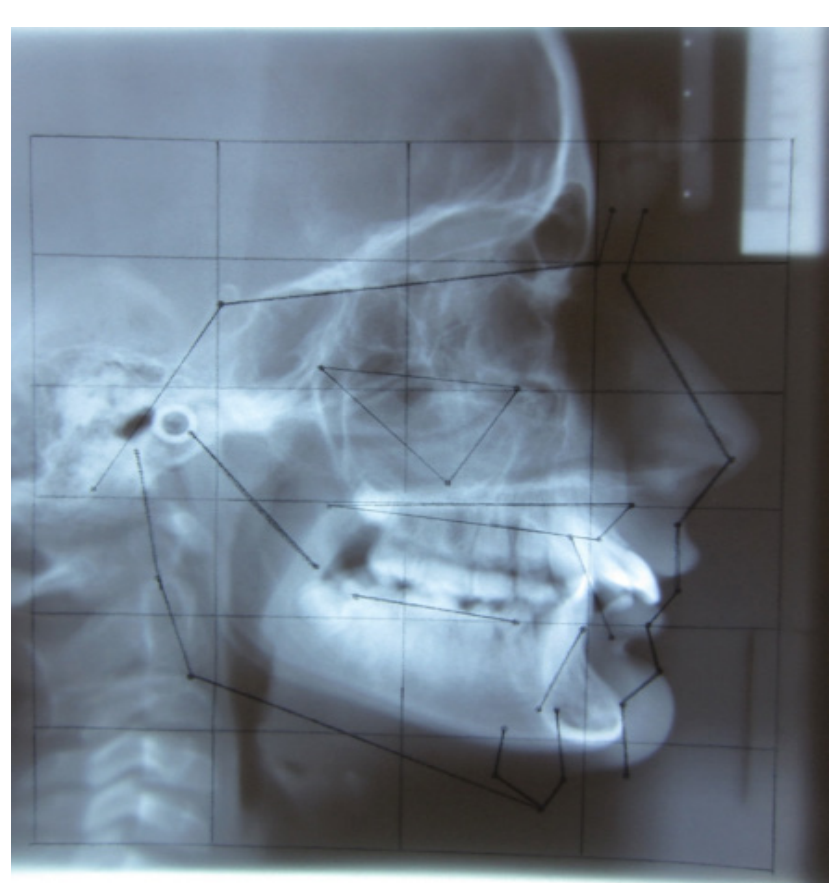

Figure 10. D.A., male, 14 years, Angle class II, anterior rotated mandible, prominent chin, protruded upper incisors.

Individual variations in the position of facial and dental points are due to different facial types of the studied subjects and translate into the appearance on Moorrees diagram of some ellipses. An elongated ellipse indicates that the points are located predominantly along its long axis $[15,16]$. There were no variations at the N-point, nor at the ANS-point, due to the fact that ANS is used by its projection to the vertical line through N. Besides facial type, variations also occurred due to sex, with a prognathous maxilla to female gender, fact that is also highlighted in our study.

Understanding craniofacial growth and development is important for accurate diagnosis, treatment planning and post-treatment evaluation of orthodontic cases. The anterior cranial base is considered to have completed its most significant growth prior to other facial skeletal structures [17]; therefore, cranial base structures and its landmarks have been used extensively as a stable reference structure in standardized records of dento-facial structures relationship, orthodontic diagnosis and treatment planning. SN line is frequently used as a reference line to assess growth of both jaws [18]. Apparently, both sella and nasion could be displaced during growth and give rise to erroneous results when that line is used as the reference [19]. A study of nine years showed the relatively stable angle between FH and SN and a constant relationship of Po, Or, S and N points to one another [20].

For Puerto Rican Americans, a lower vertical position of the S-point in the female sex was observed, resulting in a higher rotation in the lower direction of the base of the skull [21]. The horizontal points were evaluated along the base of the skull (SN line). Minor variations of the S-point in the vertical plane were also noticed for African Americans, due to the different inclination of the skull base for the patients under study [22]. In our study, there were no noticeable variations of the position of S-point.

Superimposing individual mesh diagrams can be done at $\mathrm{N}$ - point level by rotating the diagram progressively until the horizontal and vertical reference line overlap. At this time a deviation from the standard norms can be established, facilitating the orthodontic and surgical treatment plan $[19,20]$.

For each of the interpretation techniques, computerized programs have appeared. These programs include the whole information from marking the teleradiography to the diagnosis or, after a previous copy they interprets the data by one of the methods [21,22].

Cephalometric measurements on radiographic images may be subject to errors in different working steps, such as: radiographic projection, measurement system, point mark, growth prediction [23].

For each of the interpretation techniques, computerized programs have appeared. These programs include the whole information from marking the teleradiography to the diagnosis or, after a previous copy, interprets the data by one of the methods [24,25].

\section{Conclusions}

1. Moorres-like mesh diagram is not a treatment plan; it comes to support a better perspective of the anatomical elements of the dentomaxillary system and the facial growth, in predicting treatment.

2. The current study contains a relatively small number of patients, but is a beginning in this area, that can be enriched by adding patients and recalculating on average values.

3. The errors of drawing anthropometric points can be corrected with tracing cephalometrics computerized programs.

4. Computer based programs with mesh diagrams adapted to Romanian patients may be created, excluding the radiological films and tracing paper, and giving a greater accuracy of diagnosis and treatment plan. They may be the object of further studies.

\section{References}

1. Pastorek NJ. The Female Beautiful Face. JAMA. 2017;317:1198-1200.

2. Thompson DW. On Growth and Form. $2^{\text {nd }}$ ed. Cambridge: Cambridge Universitary; 1942.

3. Șerbănescu A, Corega C, Corega MA. Teleradiografia în ortodonție [Teleradiography in orthodontics]. Cluj-Napoca: Editura Medicală Universitară Iuliu Hațieganu; 2008.

4. Lupu G, Cristea B, Diaconescu B, Stroică L. Anatomia omului- Cap și Gât [Human anatomy - Head and neck]. 
București: Editura Universitară Carol Davila; 2010.

5. Ionescu E, Milicescu ID, Popescu M, Popoviciu O, Milicescu V. Ortodonție şi Ortopedie Dento- Facială- Ghid Clinic şi Terapeutic [Orthodontics and dento-facial orthopedics Clinical and therapeutic guide] București: Cerma; 2001.

6. Moorrees CFA. Nomal variation and its bearning on the use of cephalometric radiographs in orthodontic diagnosis. Am J Orthod. 1953;39:942-950.

7. Moorrees CF, uan Venrooij ME, Lebret LM, Glatky CG, Kent RL, Reed RB. New norms for the mesh diagram analysis. Am J Orthod. 1976;69:57-71.

8. Jiang $\mathrm{J}, \mathrm{Xu} \mathrm{T}$, Lin $\mathrm{J}$, Harris EF. Proportional analysis of longitudinal craniofacial growth using modified mesh diagrams. Angle Orthod. 2007;77:794-802.

9. Currie K, Sawchuk D, Saltaji H, Oh H, Flores-Mir C, Lagravere M. Posterior cranial base natural growth and development: A systematic review. Angle Orthod. 2017;87:897-910.

10. Lebret LML. The mesh diagram. A guide to its use in clinical orthodontics. In: Jacobson A, Caufield PW. Introduction to radiographic cephalometry. Philadelphia; 1985.

11. Grammer K, Thornhill R. Human (Homo sapiens) facial attractiveness and sexual selection. the role of symmetry and averageness. J Comp Psychol. 1994;108:233-242.

12. Martin R, Saller K. Lehrbuch der Antropologie. $3^{\text {rd }}$ ed. Stuttgart: Gustav Fischer Verlag; 1957.

13. Moorrees CFA, Kean MR. Natural head position: A basic consideration for the analysis of cephalometric radiographs. J Phys Anthropol. 1958;16:213-234.

14. Moorrees CF, Efstratiadis SS, Kent RL Jr. The mesh diagram for analysis of facial growth. Proc Finn Dent Soc. 1991;87:33-41.

15. Perillo M, Beideman R, Shofer F, Jacobsson-Hunt U,
Higgins-Barber K, Laster L, et al. Effect of landmark identification on cephalometric measurements: guidelines for cephalometric analyses. Clin Orthod Res. 2000;3:29-36.

16. Broca M. Sur les projections de la fete, et sur un nouveau procede de cephalometrie, Bull Soc Anthropol. Paris. 1862;3:514-544.

17. Bastir M, Rosas A, O’Higgins P. Craniofacial levels and the morphological maturation of the human skull. J Anat. 2006;209:637-654

18. Afrand M, Ling CP, Khosrotehrani S, Flores-Mir C, Lagravère-Vich MO. Anterior cranial-base time-related changes: A systematic review. Am J Orthod Dentofacial Orthop. 2014;146:21-32.e6.

19. Springate SD. A re-investigation of the relationship between head posture and craniofacial growth. Eur J Orthod. 2012;34:397-409.

20. Greiner P, Müller B, Dibbets J. The angle between the Frankfort horizontal and the sella-nasion line. Changes in porion and orbitale position during growth. J Orofac Orthop. 2004;65:217-222.

21. Evanko AM, Freeman K, Cisneros GJ. Mesh diagram analysis: developing a norm for Puerto Rican Americans. Angle Orthod. 1997;67:381-388.

22. Faustini MM, Hale C, Cisneros GJ. Mesh diagram analysis: developing a norm for African Americans, Angle Orthod. 1997;67:121-128.

23. Stanciu D, Dorobăț V. Ortodonție și Ortopedie Dento-Facială [Orthodontics and dento-facial orthopedics]. București: Editura Medicală; 2009.

24. Stanciu D, Boboc L. Ortodonție Practică [Practical orthodontics]. București: Editura Medicală; 2000.

25. Cocarla E. Ortodonție [Orthodontics]. Cluj-Napoca: Editura Iuliu Haţeganu; 2000. 